Итак, орел наделен у М.И. Цветаевой такими чертами, как отвага, свободолюбие, власть, физическая сила, одиночество и величие. Он важнейший символ, эмблема всевидящих богов неба и солнца, правителей и воинов.

\title{
Литература:
}

1. Зуева-Озкан В. Б. Образ воительницы в поэме «Царь-девица»: к вопросу о характерологии М. Цветаевой. Новый филологический вестник. 2016. № 4 (39). С. 71-86

2. Ефремова. Т. Ф. Современный толковый словарь русского языка. Москва: АСТ, 2006. 976 с.

3. Кудрявцева Е. Л. Опыт семантического анализа стихотворения Марины Цветаевой «Никто ничего не отнял» на спецсеминаре по лингвопоэтике. Констрантин Бальмонт. Марина Цветаева и хулдожественные искания $X X$ века: межвузовский сборник научных трудов. Иваново : ИГК, 1999. Вып. 4. С. 192-194

4. Лаврова Е. Л. Художественный мир М. Цветаевой : поэтика стихий : монография. Горловка : Коллегия, 2014. 323 с.

5. Скрипова О.А. «Быть голубкой его орлиной»: образы птиц в книге стихов М. Цветаевой «Ремесло». Филологический класс. 2019. № 2. C. $207-212$.

6. Трессидер Д. Словарь символов. М. : ФАИР-ПРЕСС, 1999. 448 с.

DOI https://doi.org/10.30525/978-9934-588-90-7-3

\section{PRINCIPLES OF IDIOM DESCRIPTION AS A METHODOLOGICAL BASIS OF MODERN DIALECTOLOGICAL DESCRIPTION}

\author{
Hromko T. V. \\ Candidate of Philology, \\ Associate Professor at the Ukrainian Language Department \\ Volodymyr Vynnychenko Central Ukrainian State Pedagogical University \\ Kropyvnytskyy, Ukraine
}

Description as a descriptive study of a particular usus in modern linguistics demonstrates the unlimitedness of the issues and methods of presentation of the material. Such studies of the idiom are (1) the most detailed source of information about the composition of dialect vocabulary and features of its 
functioning, because the theoretical basis of most such works in Ukrainian linguistics is the analysis of vocabulary in terms of system, "regardless of literary language vocabulary or other forms of language" [2, p. 9], and at the same time is (2) the defining basis for the established segmentation of extraverbal space, which exists in the minds of the bearers of a separate usage. Description is an aspect of typology - studies the idiom system as a unity in which the actual dialectal elements and elements of literary language coexist, and provides segmentation of all its language levels (phonetic, lexical, grammatical) as a whole system [3, p. 99], which contributes to the possibility solving general theoretical problems of studying the idiom, as well as focusing the extrapolated material on the practical value.

The principles of idiom description are the criteria of scientific and analytical actions, methodological bases, on which this type of dialectological research is based. When describing almost the entire repertoire of relevant phenomena of speech is classified, becomes available for description and analysis as a structurally ordered integrity. The experience of the theoretical approach and practical implementation of speech descriptions shows that such criteria can be distinguished on the basis of different differential features and on the basis of different approaches. Thus it is possible to allocate the basic, general for research of any, principles of monographic research:

1. Continuity of theoretical dialectological descriptions of dialects. Any idiom phenomena when describing a certain linguistic material is always based on existing linguistic traditions. These include not only Ukrainian studies, but also other Slavic languages, where this scientific field has already been established. Descriptions based on complete lexicographic descriptions are especially valuable both for the description and for the perspective of a monographic description of an idiom.

2. Reliance on modern theoretical knowledge in the field of Ukrainian dialectology. Principles of classification of languages and dialects are one of the most fragmented problems of both the Ukrainian language and general linguistics. There are no sufficient theoretical justifications for determining the type of not only adverbs but also smaller units of language. The concept of "group of dialects", which complements the classification scheme, stands out. Today the dialect of the city is considered from a different perspective.

3. Reliance on fixed in a certain way empirical material possessed by Ukrainian dialectology. When describing, almost all dialect material is relevant (data of various kinds and types of dictionaries, atlases, and audio and text libraries). In addition, it becomes modernly available for description and analysis as a certain structurally ordered integrity (for example, in the relevant corpora). 
4. Attention to all levels of empirical data (historical, folklore, ethnographic materials in various forms and manifestations), based on a comprehensive understanding of the relevance of a study. Even single data in folklore studies concerning the idiom, where a certain material is recorded, can be a useful source for description.

5. Orientation of research data on the multimedia dialect corpus of language. Corpora of dialectal language, reflecting communication and speech (in a particular locality), and large arrays of coherent speech, stored in machine-processed form, in the future will be the main source of studying the communicative specificity of dialects. The use of materials of such corpora makes it possible not to be limited to individual examples, but to move on to identify general principles, trends in dialect communication.

The general principle of forming the basic idiom for the study of speech the textual basis of the corpus - is the principle of complete and adequate reflection in the corpus of the specifics of dialect communication. The implementation of this principle involves filling the relevant subcorpora (sound, text, lexicographic) with a variety of significant textual material, representing:

- the most important types of dialect language (household language, folklore, language in terms of official, ceremonial communication);

- various forms of language (dialogue, polylogue, monologue);

- various topics of communication;

- social differentiation of speakers (by gender, age, profession, level of education), etc.

Based on the observation of empirical material that could extrapolate the idiom in the description, we come to a number of conclusions:

1) The current differential system of dialect units needs unification.

2) To describe dialect units requires not a three-stage, but even a multistage system.

3) The classification is based on the history and current state of each of its elements.

4) Break down the vocabulary into dialects using an electronic thesaurus. This shows the representation of the dialect.

5) Taking into account in the classification not only the criteria of ancient settlement, but also migrations of the population, carriers of various idioms, in the period XX - early XXI century.

6) Taking into account the vocabulary not only outdated, but also innovative processes, various thematic groups.

7) Peculiarities of the folk mentality influenced the specifics of the language situation, namely: the coexistence of vernacular types of speech (rural vernacular, literary language (or several), dialects of other languages, etc.). 
Today we can not underestimate the importance of atomic research (dialectological descriptions of thematic groups of vocabulary, individual words, etc.), so the description of the idiom as a combination of theoretical and practical layers has its place in linguistics. For dialectological science, of course, more significant are the works in which "methodology and methods in action" are presented [1, p. 123].

Thus, the principles of idiom description are focused on taking into account the complex linguistic study of the idiom as a set of a significant number of dialect units. As a methodological basis of modern dialectological description, atomic linguistic interpretation of all language levels of the idiom on the basis of observation of the originality of folk speech determine the modern approach to the synchronous description of dialect stratum.

\section{References:}

1. Герд А. С. Введение в этнолингвистику. Курс лекций и хрестоматия. 2-е изд., исправл. СПб.: Изд-во С.-Петерб. ун-та, 2005. 457 с.

2. Гриценко П. Ю. Українська діалектна лексика: реальність і опис (деякі аспекти). Діалектна лексика: лексикологічний, лексикографічний та лінгвогеографічний аспекти. Матеріали доповідей Міжнародної наукової конференції. Глухів, 2005. С. 5-33.

3. Hromko T. V. Methods of collecting material for speech description. Paradigmatic view on the concept of world science: Collection of scientific papers $\langle\Lambda \mathrm{O} Г \mathrm{O} \Sigma$ » with Proceedings of the International Scientific and Practical Conference 2020. Vol. 2. Toronto, Canada: European Scientific Platform. P. 99-101. DOI: 10.36074/21.08.2020.v2.

DOI https://doi.org/10.30525/978-9934-588-90-7-4

\section{ДОСЯГНЕННЯ СУЧАСНОЇ УКРАЇНСЬКОЇ ЛЕКСИКОГРАФІЇ}

\section{Давиденко В. I.}

кандидат філологічних наук, доцент, докторант кафедри прикладної лінгвістики, порівняльного мовознавства та перекладу

Національний педагогічний університет імені М. П. Драгоманова м. Київ, Україна

Значення і вплив лексикографії останнім часом стрімко і невпинно зростає, що обумовлено сучасними запитами суспільства, розвитком, 